\title{
Environmental change and Rift Valley fever in eastern Africa: projecting beyond HEALTHY FUTURES
}

\author{
David Taylor, ${ }^{1}$ Michael Hagenlocher, ${ }^{2}$ Anne E. Jones, ${ }^{3}$ Stefan Kienberger, ${ }^{2}$ Joseph Leedale, ${ }^{3}$ \\ Andrew P. Morse ${ }^{3,4}$ \\ ${ }^{1}$ Department of Geography, National University of Singapore, Singapore; \\ ${ }^{2}$ Department of Geoinformatics - Z_GIS, University of Salzburg, Salzburg, Austria; \\ ${ }^{3}$ School of Environmental Sciences, University of Liverpool, Liverpool; \\ ${ }^{4}$ National Institute of Health Research, Health Protection Research Unit in Emerging \\ and Zoonotic Infections, Liverpool, UK
}

\begin{abstract}
Outbreaks of Rift Valley fever (RVF), a relatively recently emerged zoonosis endemic to large parts of sub-Saharan Africa that has the potential to spread beyond the continent, have profound health and socio-economic impacts, particularly in communities where resilience is already low. Here output from a new, dynamic disease model [the Liverpool RVF (LRVF) model], driven by downscaled, bias-corrected climate change data from an ensemble of global circulation models from the Inter-Sectoral Impact Model Intercomparison Project run according to two radiative forcing scenarios [representative concentration path-
\end{abstract}

Correspondence: David Taylor, Department of Geography, National University of Singapore, 1 Arts Link, Kent Ridge, Singapore.

Tel: +65.6516.3851 - Fax: +65.6777.3091.

E-mail: david.taylor@nus.edu.sg

Key words: Climate change; East African Community; Health; Infectious disease; Zoonosis.

Acknowledgements: we are sincerely grateful to the European Union's Seventh Framework Programme (FP7/2007-2013) for funding the research that underpins this paper through grant agreement no. 266327. Thanks are due to the many contributors to the HEALTHY FUTURES project (www.healthyfutures.eu), notably staff at the International Livestock Research Institute (ILRI) in Kenya, to the organisers of the Impact of Environmental Changes on Infectious Diseases (IECID) conference, held in Spain in March 2015, to Elsevier and Trinity College Dublin for financial support for the HEALTHY FUTURES session at the IECID conference, to Poonam Saksena-Taylor for help with Figure 1, and to those who have provided comments, pre-submission, on earlier versions of the manuscript.

Received for publication: 15 June 2015.

Revision received: 4 December 2015.

Accepted for publication: 4 December 2015.

CCopyright D. Taylor et al., 2016

Licensee PAGEPress, Italy

Geospatial Health 2016; 11(s1):387

doi:10.4081/gh.2016.387

This article is distributed under the terms of the Creative Commons Attribution Noncommercial License (CC BY-NC 4.0) which permits any noncommercial use, distribution, and reproduction in any medium, provided the original author(s) and source are credited. way (RCP)4.5 and RCP8.5], is combined with results of a spatial assessment of social vulnerability to the disease in eastern Africa. The combined approach allowed for analyses of spatial and temporal variations in the risk of RVF to the end of the current century. Results for both scenarios highlight the high-risk of future RVF outbreaks, including in parts of eastern Africa to date unaffected by the disease. The results also highlight the risk of spread from/to countries adjacent to the study area, and possibly farther afield, and the value of considering the geography of future projections of disease risk. Based on the results, there is a clear need to remain vigilant and to invest not only in surveillance and early warning systems, but also in addressing the socio-economic factors that underpin social vulnerability in order to mitigate, effectively, future impacts.

\section{Introduction}

The health effects of future environmental, including climate, changes are projected to be substantial, often negative and to vary geographically (Costello et al., 2009; Curtis and Oven, 2012; McMichael et al., 2012; Semenza, 2014). The effects will be felt most acutely among the poorest members of society, who already carry a disproportionately high share of the burden of environmentally sensitive diseases (Campbell-Lendrum et al., 2015). Environmental change will impact health in a multitude of ways. Concern has, however, tended to focus on the future distribution and spread of infectious diseases, and in particular the negative health impacts of changes in transmission and outbreaks of vector borne diseases (VBDs). The impacts may be direct, in terms of outbreaks of disease among human populations, or indirect, in the form of outbreaks of diseases that affect domesticated animals or plants, and therefore jeopardise food security, agriculturebased economic activities and trade. Many of the diseases of greatest concern are zoonotic (Jones et al., 2013), i.e. they normally circulate in vertebrates other than humans but possess the potential to infect people. Moreover, climatically tropical parts of the world are foci of zoonotic outbreaks (Jones et al., 2008), an association that, on face value at least, would appear to have major implications for biosecurity in more temperate parts of the world under conditions of a warming Earth (Barker, 2012).

Pathogens that spend time outside the human body, and any organisms involved in their transmission (vectors and intermediate hosts), have particular environmental requirements. For example, arthropod vectors (e.g. mosquitoes) are only able to regulate their internal temperature by changes in behaviour and distribution (Lindsay and Birley, 
1996). Accordingly, variations in ambient temperature could trigger a complex of responses, potentially including changes in behaviour, distribution and population dynamics. Variations in pathogenicity are also likely. Rainfall also impacts transmission and outbreaks of VBDs such as malaria (Gubler et al., 2001), dengue (Degallier et al., 2010) and Rift Valley fever (RVF; Linthicum et al., 1999). High levels of precipitation can increase the extent of suitable habitat for water-related vectors such as mosquitoes, while raised humidity can increase vector survival rates. Conversely, high levels of rainfall can lead to reduced vectorial capacity (Paaijmans et al., 2009), for example by making oviposition impossible (Day et al., 1990). Low rainfall, by reducing river flow and by encouraging the storage of water close to houses, can also expand habitats (Pontes et al., 2000; Kovats et al., 2003). Climate conditions may also have indirect effects on infectious disease burdens. Prolonged drought may necessitate the sharing of available surface water resources with livestock, thereby increasing transmission opportunities for zoonotic diseases (Blancou et al., 2005) and rendering those infected yet more vulnerable to other drought related ailments, while flooding can seriously undermine the effective provision of health services, as experienced during recent outbreaks of RVF in eastern Africa (Jost et al., 2010). Aside from climate, changes in land use can also dramatically influence the dynamics of infectious diseases (Gottdenker $e t$ al., 2015).

The cause and the effectiveness of responses to disease outbreaks is determined by a complex of factors that extend beyond the biology and ecology of the vector and pathogen to include, for example, the immunity and resilience of the host, standard of sanitation, quality of housing, poverty, accessibility and quality of health care, movement of people and animals, level of education and awareness of the disease. This complex frames vulnerability to a VBD (Scott et al., 2012). Accounting for the complex of factors underpinning social vulnerability, or what Lambin et al. (2010) term the pathogenic landscape, is crucial to meaningful estimates of the risk of an infectious disease (Weiss and McMichael, 2004), while also highlighting where interventions aimed at reducing exposure or boosting resilience might be most effectively targeted (Kienberger and Hagenlocher, 2014). Moreover, any response that does not deal with the full range of factors contributing to vulnerability of the population runs the risk of more deeply entrenching an epidemiology of inequality - the socio-economic inequalities that lead to sickness and poor health (Sparke and Anguelov, 2012).

Sub-Saharan Africa is commonly regarded as one of, if not the, world's most vulnerable regions to the health impacts of climate change (Bartlett, 2008; Bernstein and Myers, 2011). The HEALTHY FUTURES project focused on sub-Saharan, eastern Africa, and in particular the five member states comprising the East African Community (EAC), and three VBDs. Two of the VBDs studied, malaria and schistosomiasis, have a major impact on human health in the study region, and more broadly in sub-Saharan Africa. The third VBD, RVF, is an acute zoonosis caused by a virus (RVFV) belonging to the genus Phlebovirus of the family Bunyaviridae (Martin et al., 2008) that mainly impacts livestock in affected areas but that can also cause illness, and death, among humans. Regarded as endemic to large parts of subSaharan Africa, RVF has also been recorded from north Africa (Egypt), in addition to the Middle East and the island of Madagascar (Figure 1). The disease has the potential for global spread, as demonstrated by its recent rapid range expansion, the large number and wide distribution of competent vectors, the broad ecological tolerance of the RVF virus (RVFV), the intense viraema associated with infection and an extension of suitable habitat as a result of environmental change (Gerdes, 2004; Weaver and Reisen, 2010; Sindato et al., 2014).

The main RVFV activity occurs in forest edge and bushed and wood- ed grassland habitats, with the most severe outbreaks associated with bodies of shallow, standing water (Peters and Meegan, 1994). The latter may be linked to unusually high levels of rainfall, as in eastern and southern Africa, or to land use, particularly large irrigation schemes, in drier, northern and western parts of the continent (Chevalier et al., 2004). The RVFV is mainly transmitted by arthropods and, more rarely, through contact with blood and other bodily fluids from infected animals. Although a large number of potentially competent arthropod vectors of RVFV have been identified (Gerdes, 2004; Turell et al., 2010; Chevalier et al., 2010; Tantely et al., 2015), two genera of mosquito are principally involved in transmission. These are members of Aedes (the reservoir vector, generally thought to be responsible for maintaining the disease through the inter-epizootic period in endemic areas, including through vertical transmission from adult to egg) and Culex (the amplifying vector, members of this genus must bite an infected host in order to become infected and are responsible for the rapid spread of RVF associated with epizootic outbreaks) (Anyamba et al., 2010). There is some evidence that the RVFV may influence behavior of vectors in such a way that enhances transmission rates. Gad et al. (1989) suggest that mosquitoes infected with the virus are less able to engorge with blood, and therefore are likely to probe and feed off a host more frequently.

Aedes and Culex taxa differ in their breeding site preferences and therefore in their response to rainfall. Thus the eggs of Aedes spp., oviposited on damp ground at the sloped edge of wet depressions, can remain viable in the soil for months even years before hatching following a re-wetting of the substrate (Pépin et al., 2010). By comparison, Culex taxa lay their eggs on the surface of standing water, and therefore greatly increase in abundance following flooding (Bird et al., 2009). Epizootic outbreaks are highly episodic, with a periodicity of 10 15 years that rises to more than 30 years in the most drought prone areas (Gerdes, 2004) and are associated with unusually prolonged periods of heavy rain that generates suitable breeding sites for Culex spp. (Beaty and Marquardt, 1996). In Africa, prolonged periods of anomalously high levels of rainfall, and heightened activity of RVFV, are often associated with the El Niño Southern Oscillation (ENSO, El Niño in eastern and La Niña in southern Africa) (Anyamba et al., 2014).

Among domesticated ungulates RVFV causes substantial morbidity and mortality and, particularly in sheep, levels of abortion of up to $100 \%$ (Anyamba et al., 2012). Young animals are most at risk, as are high yielding, non-native varieties of livestock (Chevalier et al., 2004). In humans, RVF often presents as moderate to severe, non-fatal fever (Gerdes, 2004), although the vast majority of infections remain unapparent. Up until recent outbreaks, less than one percent of infected humans developed the more severe hemorrhagic and/or encephalitic forms of the disease. As there is no cure, management of RVF cases has been through supportive therapy (Pawseka and van Vuren, 2013), although preventative vaccinations exist for livestock (Glyn Davies and Martin, 2006).

This paper provides a preliminary assessment of the future risk of RVF within eastern Africa (more specifically, the EAC region). Leedale et al. (2016) describe development of a dynamic, process-based, climate-driven model for RVF (the Liverpool RVF, or LRVF, model) through HEALTHY FUTURES. The LRVF model, described in more detail below, is used in the current paper: output from the model is in the form of climatically driven, spatially and temporally varying estimates of the entomological inoculation rate (EIR), a commonly used measure of the intensity of transmission of a VBD, for a livestock host. Combining the estimates of EIR with determinations of levels of current social vulnerability to RVF in the EAC, using a technique similar to that described in Kienberger and Hagenlocher (2014), provided a means of assessing 
projected differences in risk and a basis for comparison with the current situation. Changes in the distribution and extent of hotspots of relatively high risk are discussed. The results are used as a basis for looking beyond HEALTHY FUTURES, both geographically and into the future.

\section{Materials and Methods}

\section{Study area}

The study area incorporated the eastern African countries that comprise the EAC (the republics of Burundi, Kenya, Rwanda and Uganda and the United Republic of Tanzania). Regional cooperation to ensure a completely healthy society within member states challenged by environmental and economic transformatios is a key component of the (currently being finalised) Protocol on East African Community
Regional Cooperation on Health. The study area serves as a useful basis for a combined approach to assessing the effects on VBDs of environmental, socio-economic and demographic conditions. A range of altitude- and latitude-related environmental conditions, including extensive highland areas and a lowland coastal plain, and a range of humidity, from more or less permanently humid highlands to arid and semi-arid plains, are present, as are large freshwater bodies and extensive wetlands. A broad range in environmental conditions is matched by a rich diversity of cultures, and unevenness in the distribution of settlements, economic activities and investment in health. Many people in rural areas (rural population densities in some parts of the study area are among the highest in the world) engage in food production practices that are highly sensitive to climate variability and change and are often distant from health and veterinary services. There are no reports of epizootic outbreaks of RVF in EAC countries outside Kenya and Tanzania, although recent work by Magona et al. (2013) suggests that RVFV is endemic in goats in Uganda.

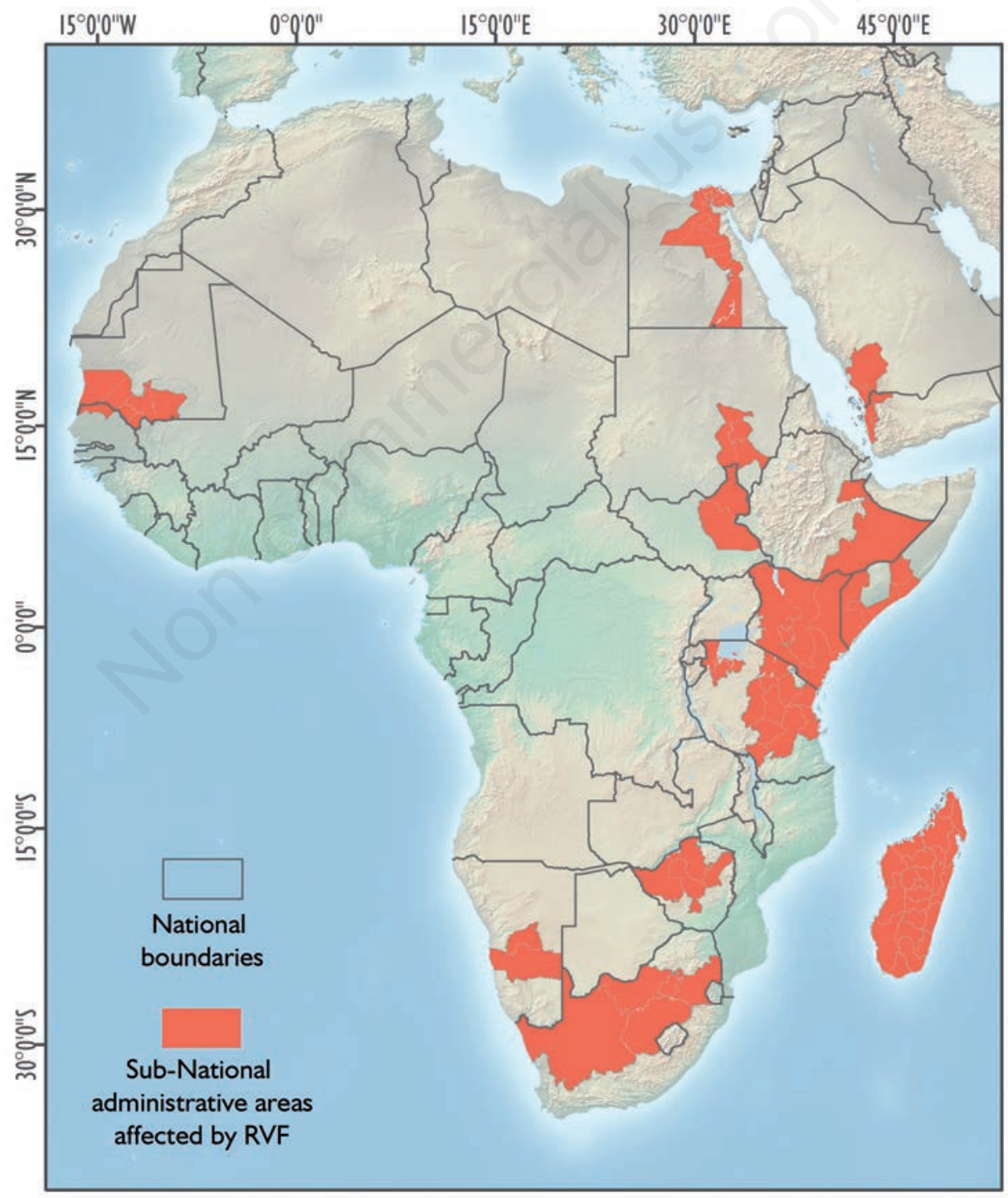

Figure 1. Distribution of main outbreaks of Rift Valley fever (dark shaded areas), based on World Health Organization (2009). 


\section{Determining risk}

Risk is viewed in the current research as a combination of hazard (i.e. spatially varying, climatically-driven estimates of the EIR for RVF) and the vulnerability of the population in affected regions (Kienberger and Hagenlocher, 2014; Hagenlocher and Castro, 2015).

The LRVF model follows a deterministic compartmental approach to the epidemiology of RVF and is based on the Liverpool malaria model (LMM), developed initially by Hoshen and Morse (2004). The model was parameterized based on information gained from eastern Africa, mainly from existing published sources but also on the basis of results of surveys carried out in Ijara District in Kenya as part of HEALTHY FUTURES (Bett et al., 2013). As Leedale et al. (2016) stress, eastern Africa proved an ideal site for LRVF model development, because of the relatively long history of the disease and the wide range of environmental conditions represented in the region.

The LRVF model takes into account the two main mosquito vectors for RVF at the generic level (i.e. Aedes spp and Culex spp.), and differences in transmission characteristics between mature and immature host livestock. The latter is important because immature livestock infected with RVFV tend to have a much higher mortality than older animals. Vector and host populations are divided into several classes in the model, based on their infection status. These classes include a recovered (R) class, with recovered hosts maintaining lifelong immunity (Wilson, 1994). The LRVF model does not consider RVFV transmission among human hosts, focusing instead on outbreaks of RVF in livestock. The model does, however, accommodate sensitivity to variations in daily temperature and precipitation exhibited by the vector component, notably the production and laying of eggs, development of larvae, and biting frequency and daily survival probability of mosquitoes. Variations in climate data are input to the model in gridded form. Model output is in the form of a map indicating spatial differences in susceptibility to RVF as a result of the input climate conditions and predicted livestock immunity. The highly episodic nature of outbreaks of RVF together with the involvement of two vectors complicates the selection of an acceptable metric of susceptibility. Here we used spatially explicit estimates of EIR as the outbreak metric from the LRVF model.

Climatically sensitive, transmission relevant components of the LRVF model were in this case driven by bias corrected output (projected climate data) from separate runs of five downscaled Global Circulation
Models (GCMs) from the Inter-Sectoral Impact Model Intercomparison Project (ISI-MIP) (Warszawski et al., 2014). The GCMs were driven by two of the four representative concentration pathway (RCP) scenarios referred to in the latest, the 5th, Assessment Report of the Intergovernmental Panel on Climate Change (IPCC) (Burkett et al., 2014). The two RCPs selected, RCP4.5 (radiative forcing peaking at 4.5 $\mathrm{W} \mathrm{m}^{-2}$ by 2100 , and known as the lower stabilisation scenario) and RCP 8.5 (radiative forcing at $8.5 \mathrm{~W} \mathrm{~m}^{-2}$ by 2100 owing to very high greenhouse gas (GHG) emissions that are still on an upward trajectory by the end of the current century), accommodate a range of plausible future GHG emission and land use changes and are thus expected to be of use in forward planning aimed at mitigating impacts (van Vurren et al., 2011).

Although the LRVF model distinguishes between the modes of transmission and breeding ground preferences for the two principal mosquito vectors involved in RVFV transmission, only the modeled EIR for Culex spp. is considered here. This is because a large spike in EIR associated with Culex spp., as the amplifying vector, likely represents an epizootic event (Leedale et al., 2016). Three time periods were simulated using LRVF and climate change data: 1980-2010 (equates to the present) and 2011-2050 (mid-century) and 2051-2099 (end of century). Here changes in EIR for Culex spp. are assumed to represent differences in epizootic susceptibility as determined by climate, or the potential for an outbreak of RVF. A peak detection method was formulated for all model variables based on upper quartile threshold values for 19802010 (based on annual means). This provided us with a quantifiable metric that allows comparisons of relative peak (or event) frequencies of a particular variable over time. The upper quartile range was used to identify relative peaks, thus allowing the proportion of relative peak years in each period to be plotted for each spatial grid-point (e.g. Figure 2 ). The current work follows previous assessments of risk and vulnerability associated with VBDs (e.g. Dickin et al., 2013; Kienberger and Hagenlocher, 2014; Hagenlocher and Castro, 2015) in equating social vulnerability in the health domain to the predisposition of a population to the burden of disease, a definition that encompasses more specifically the sub-domains of susceptibility and the lack of resilience. Social vulnerability in the sense adopted here extends beyond the exposure to disease to include the ability to anticipate, cope with and recover from outbreaks (Kienberger and Hagenlocher, 2014). Moreover, owing to the difficulty of projecting socio-economic data, and thus vulnerability, in a

Table 1. Indicators of social vulnerability to Rift Valley fever in East African Community countries.

\begin{tabular}{|c|c|c|c|c|c|c|}
\hline Indicator name & & Date & Initial resolution $^{\circ}$ & Sign $\#$ & Weight & Data source \\
\hline \multirow[t]{3}{*}{ SUS } & Tropical livestock unit & 2006 & 0.00833 degrees & + & 0.1679 & FAO \\
\hline & Aridity index & 2009 & 0.00833 degrees & + & 0.1419 & CGIAR CSI \\
\hline & Number of people living on less than 2 US\$ per day & 2010 & 2.5 arc-minutes & + & 0.2228 & CGIAR CSI \\
\hline \multirow[t]{4}{*}{$\mathrm{C} 2 \mathrm{~A}$} & Secondary/higher education (\%) & 2007/08 & Point layer & - & 0.0522 & DHS \\
\hline & Knowledge/experience with RVF & 2014 & Point layer & - & 0.1717 & FAO EMPRES-AH \\
\hline & Households with radio (\%) & $2007 / 08$ & Point layer & - & 0.0626 & DHS \\
\hline & Households with mobile phone (\%) & $2007 / 08$ & Point layer & - & 0.0418 & DHS \\
\hline \multirow[t]{2}{*}{$\mathrm{C} 2 \mathrm{C}$} & $\begin{array}{l}\text { Travel time to urban centers } \\
\text { (proxy for distance to markets) }\end{array}$ & 2010 & Point layer & + & 0.0695 & $\begin{array}{c}\text { OSM, ESA } \\
\text { GlobCover, SRTMv4 }\end{array}$ \\
\hline & Distance to road networks & 2010 & Line layer & + & 0.0695 & $\begin{array}{c}\text { OSM, ESA } \\
\text { GlobCover, SRTMv4 }\end{array}$ \\
\hline
\end{tabular}

SUS, generic susceptibility; FAO, Food and Agriculture Organization of the United Nations (http//www.fao.org/home/en/); CGIAR-CSI, Consultative Group for International Agricultural Research-Consortium for Spatial Information (http://www.cgiar-csi.org/); C2A, lack of capacity to anticipate; DHS, Demographic and Health Surveys Programme of USAID (http:/www.dhsprogram.com/); RVF, Rift Valley fever; FAO EMPRES-AH, FAO Emergency Prevention System of Animal Health (http:/www.fao.org/ag/againfo/programmes/en/empres/home.asp); C2C, lack of capacity to cope; OSM, Open Street Map (https:/www.openstreetmap.org/\#map=5/51.500/-0.100); ESA GlobCover, European Space Agency Global Cover Portal (http://due.esrin.esa.int/page_globcover.php); SRTMv4, Global Elevation data from the NASA Shuttle Radar Topography Mission, version 4 (post September 2008) (http:/www2.jpl.nasa.gov/srtm/). Indicators and their weightings determined through discussions with 24 domain experts in the region. ${ }^{\circ}$ Initial resolution refers to the spatial resolution of the original datasets (i.e., before the data was resampled to $\left.10 \times 10 \mathrm{~km}^{2} \mathrm{grids}\right)$; ${ }^{\sharp}$ sign indicates whether increased indicator values translate into increased (+) or reduced (-) risk. 
spatially explicit manner into the future, estimated differences in vulnerability within the study area were held constant over the period of interest (the current century). In order to map spatial variations in predisposition to RVF a set of indicators of vulnerability first had to be agreed upon, quantified (if necessary), weighted and rendered suitable for incorporation in a spatially explicit vulnerability index for subsequent mapping. The list, quantification and weighting of indicators were arrived at through consultations with 24 RVF experts in eastern Africa. A total of nine indicators was selected and divided into three categories corresponding to different components of vulnerability (Table 1): generic susceptibility underpins general predisposition of livestock to the disease, whereas the capacity to anticipate and cope with RVF outbreaks determines resilience. The consultations generated much discussion, particularly around the relative importance of the nine vulner-
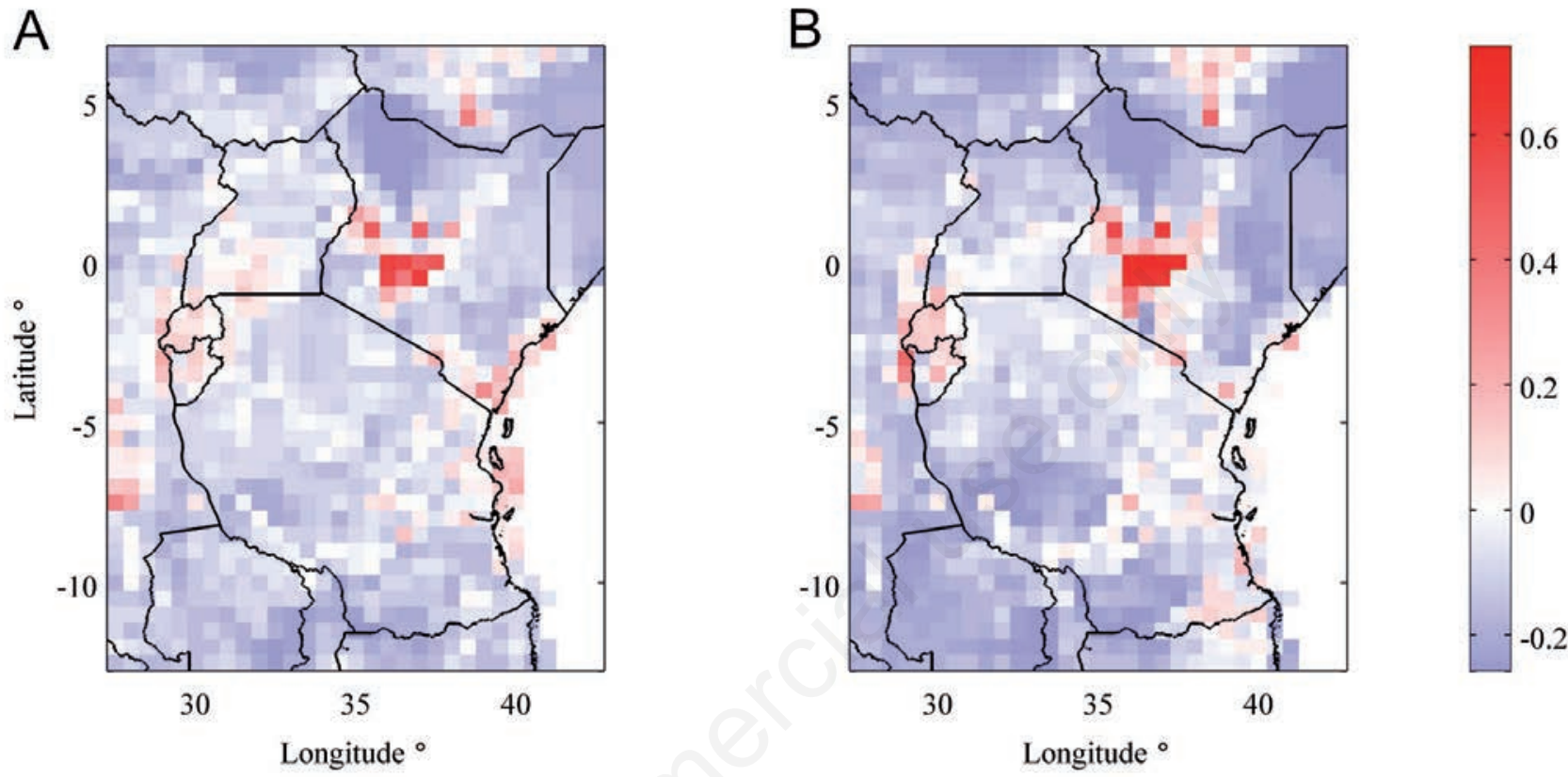

C

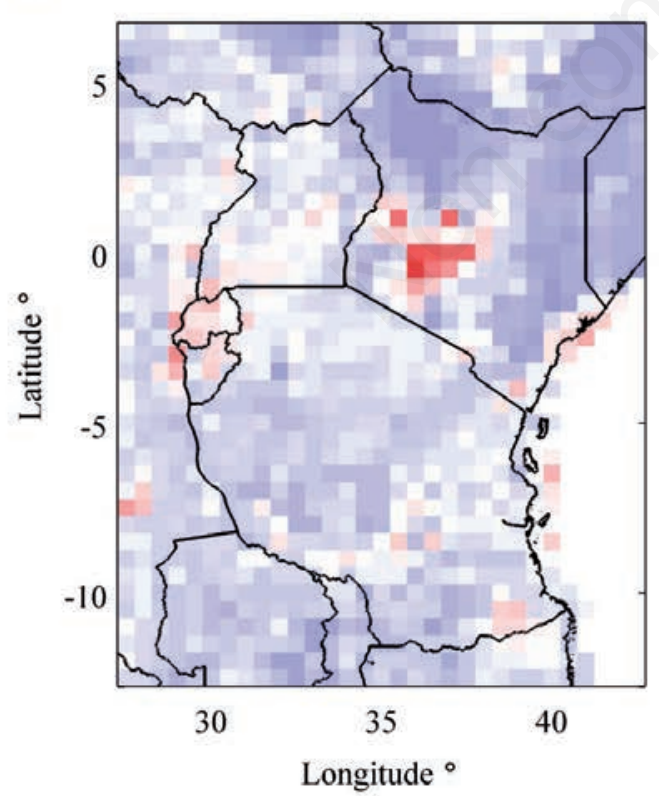

$\mathrm{D}$

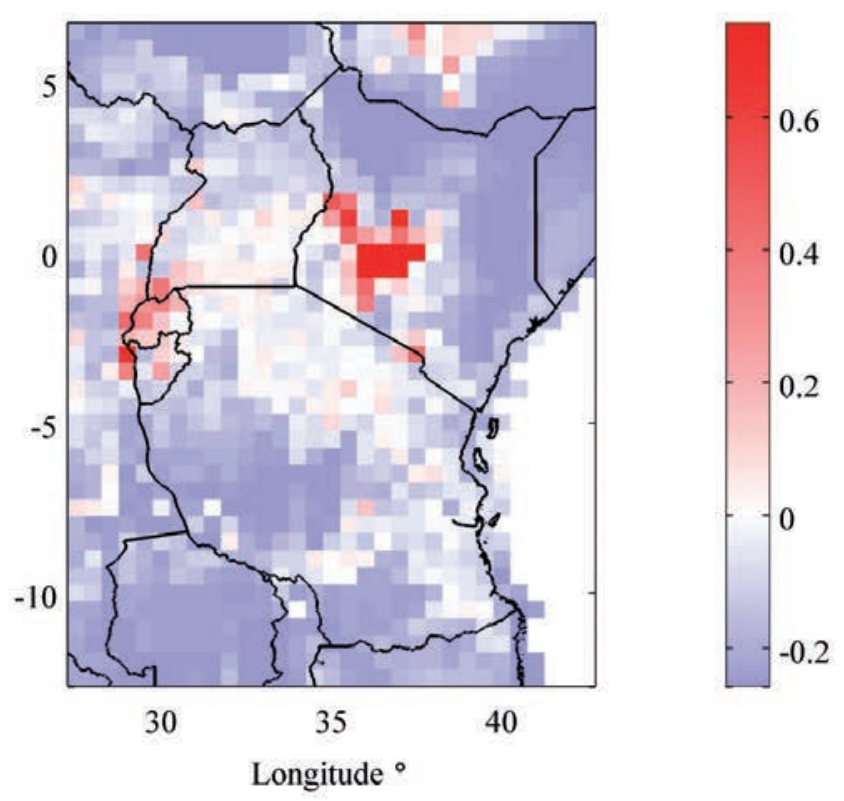

Figure 2. Changes in Culex entomological inoculation rate (EIR) peak frequency (proportion of peak years per period) in eastern Africa as projected by the Liverpool Rift Valley fever model driven by the global climate model, Geophysical Fluid Dynamics LaboratoryEarth System Model 2M. Differences in Culex EIR peaks are shown between 2011-2050 and 1980-2010 for representative concentration pathway (RCP)4.5 (A) and RCP8.5 (C), and between 2051-2099 and 1980-2010 for RCP4.5 (B) and RCP8.5 (D). By definition, the proportion of EIR Culex peak years during the baseline period (1980-2010) is 0.25 . 
ability indicators. Investigating the sensitivity of the risk assessment to variations in the weightings attributed to vulnerability indicators would be an interesting and worthwhile development of the work presented here, and provide a valuable insight into uncertainty.

Rendering of indicators prior to mapping included the interpolation of point data using kernel density estimators for demographic and health survey data, resampling to a grid of $10 \mathrm{~km} \mathrm{x} 10 \mathrm{~km}$, the identifi- cation and imputation of missing data, the detection and treatment of outliers and finally the reduction of multi-collinearities in the data (Kienberger and Hagenlocher, 2014). Mapping of homogenous spatial units of social vulnerability was based on the concept of integrated geons, a method for delineating and classifying homogenous spatial objects based on a set of multivariate gridded datasets (the integration of a set of multivariate gridded datasets through regionalization (Lang
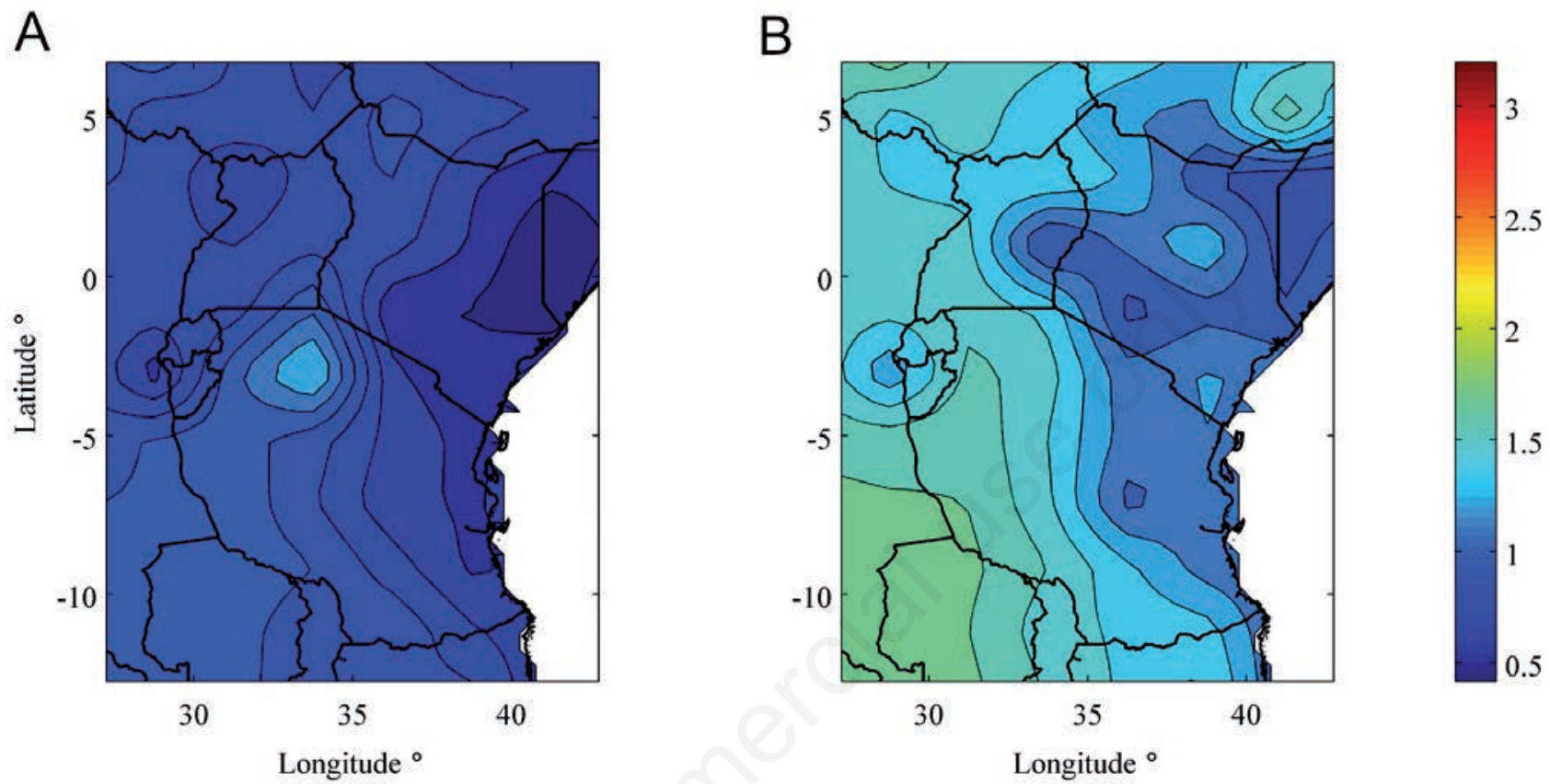

C

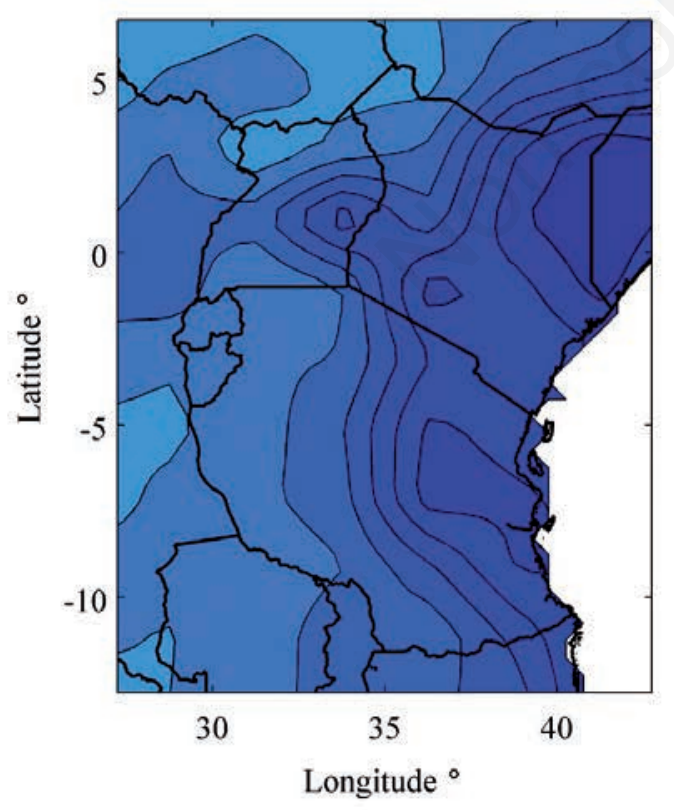

D

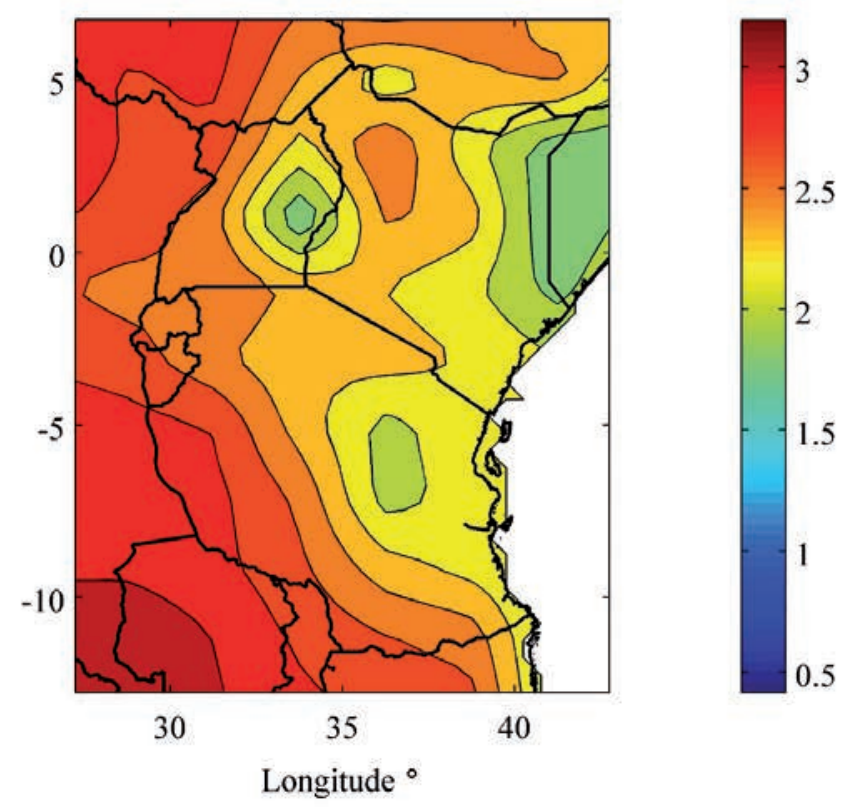

Figure 3. Changes in mean temperature $\left({ }^{\circ} \mathrm{C}\right)$ for eastern Africa as projected by the global climate model, Geophysical Fluid Dynamics Laboratory-Earth System Model 2M. Differences in mean temperature are shown between 2011-2050 and 1980-2010 for representative concentration pathway (RCP)4.5 (A) and RCP8.5 (C), and between 2051-2099 and 1980-2010 for RCP4.5 (B) and RCP8.5 (D). 
et al., 2014). Being independent of a priori defined geographies, this approach better reflects the transboundary nature of RVF risk as compared to risk assessments based on administrative units. Spatially specific estimates of risk were determined from the geometric mean of normalized levels of hazard (EIR) and social vulnerability, both of which were given equal weight due to the absence of empirical relationships between these components and RVF risk.

\section{Results}

For brevity, Figures 3-5 show output from one of the five GCMs used in the current research (Geophysical Fluid Dynamics Laboratory-Earth System Model 2M, gfdl-esm2m). The results described below should therefore be considered as demonstrative of the type of projected out-
A

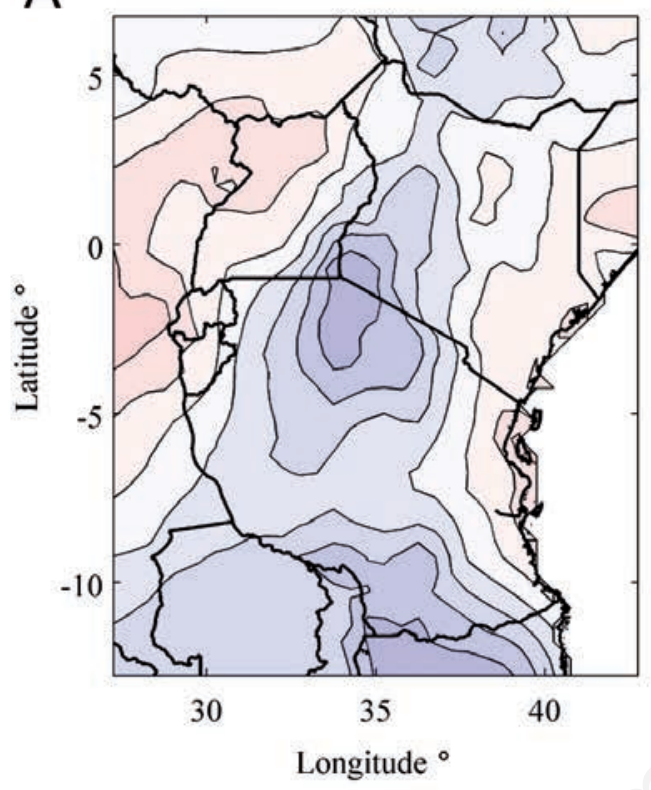

C

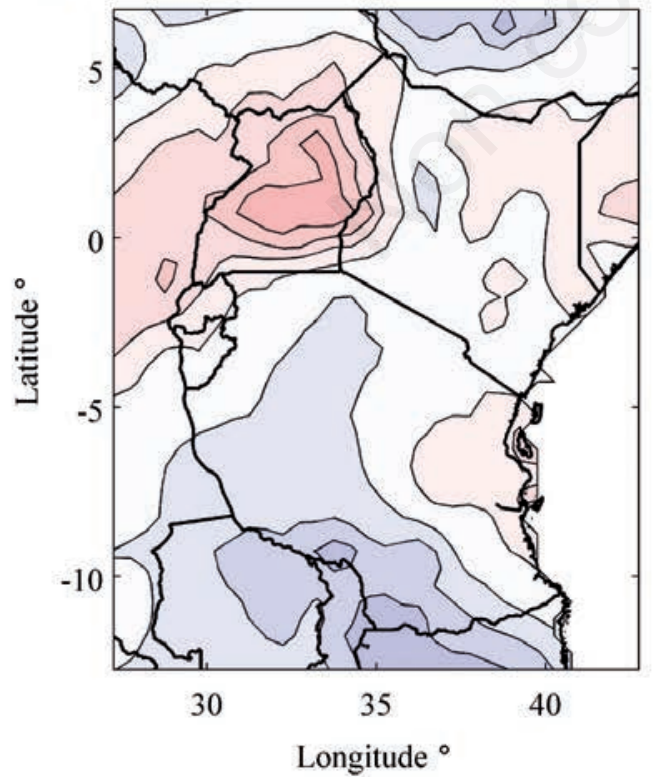

B

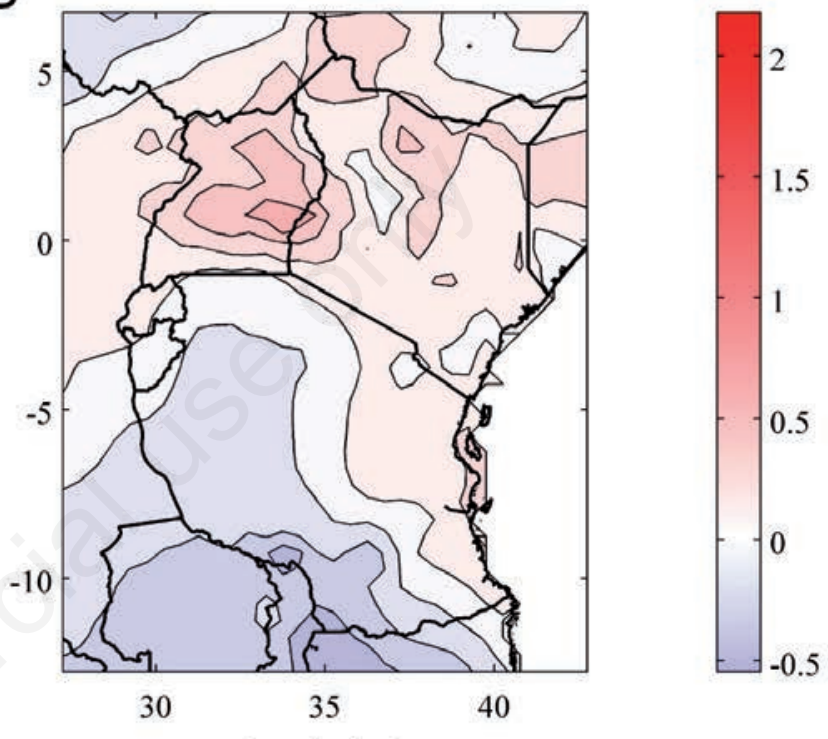

Longitude $^{\circ}$

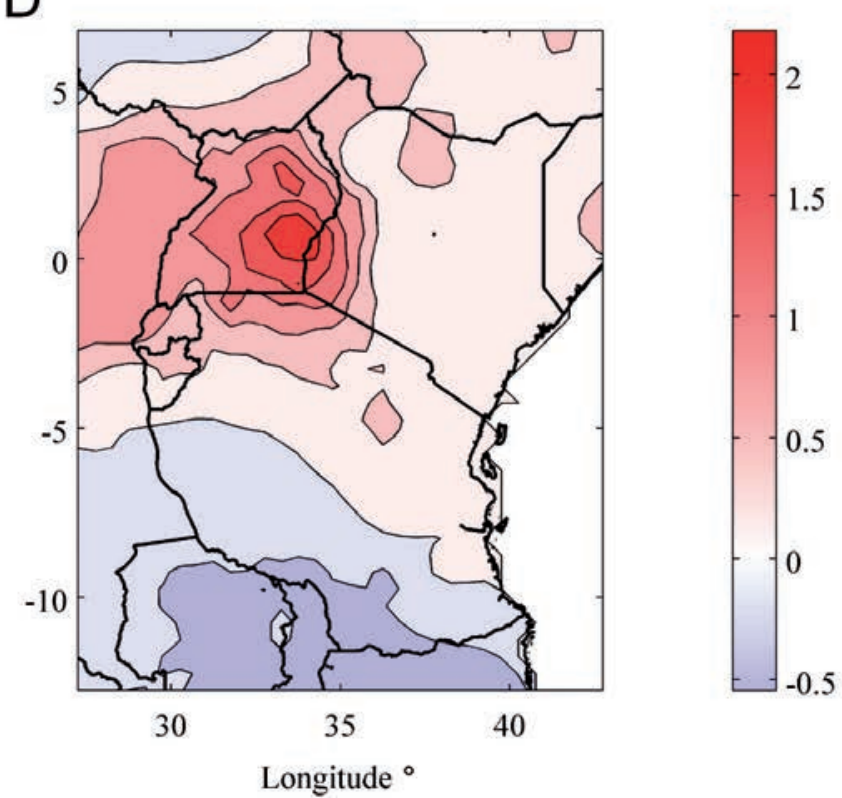

Figure 4. Changes in mean daily rainfall $\left(\mathrm{mm} \mathrm{day}^{-1}\right)$ for eastern Africa as projected by the global climate model, Geophysical Fluid Dynamics Laboratory-Earth System Model 2M. Differences in mean rainfall are shown between 2011-2050 and 1980-2010 for representative concentration pathway (RCP)4.5 (A) and RCP8.5 (C), and between 2051-2099 and 1980-2010 for RCP4.5 (B) and RCP8.5 (D). 

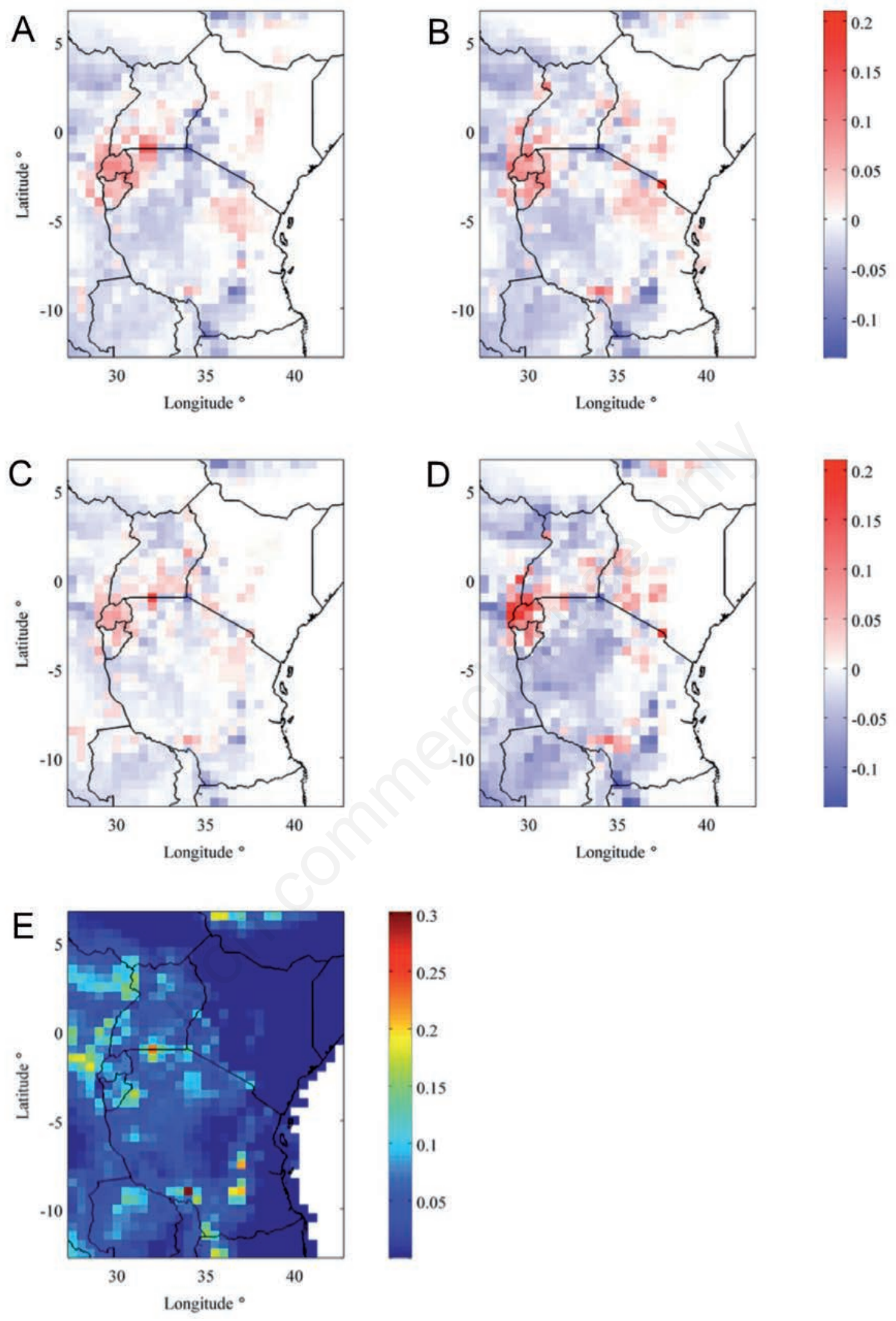

Figure 5. Changes in mean entomological inoculation rate (EIR) (number of infectious bites per animal per day) for Culex spp. in eastern Africa as projected by the Liverpool Rift Valley fever model driven by the global climate model, Geophysical Fluid Dynamics Laboratory-Earth System Model 2M. Differences in mean Culex EIR are shown between 2011-2050 and 1980-2010 for representative concentration pathway (RCP)4.5 (A) and RCP8.5 (C), and between 2051-2099 and 1980-2010 for RCP4.5 (B) and RCP8.5 (D). Mean Culex EIR for the baseline period $(1980-2010)$ is also shown $(\mathrm{E})$. 
comes a complex dynamic model, such as the LRVF, can produce, as well as an example of how such a model can add insights to the underlying processes of RVFV transmission.

Climate output from the ensemble of five downscaled GCMs for three time periods [1980-2010 (baseline), 2011-2050 and 2051-2099] for RCP4.5 and RCP8.5 suggest warming throughout the region. More variability is evident in changes in mean precipitation. Generally rainfall levels are higher throughout much of eastern Africa by 2051-2099, particularly for RCP8.5, while mean precipitation is projected to fall in the central part of the Great Rift Valley (RCP4.5) and southwestern
Tanzania (RCP4.5 and RCP8.5). Simulated changes in EIR for Culex spp. at baseline show greatest differences corresponding with the Great Rift Valley in Tanzania and Kenya for both RCPs. Thus the location of projected hotspots is in broad agreement with the main foci of past RVF outbreaks in eastern Africa, including the major one in September 2006-May 2007 (Anyamba et al., 2012). Relatively high levels of change in EIR at baseline also occur to the west of Lake Victoria, in western Uganda and into Rwanda and Burundi. The baseline distribution is thus similar to that predicted for Culex pipiens complex, closely linked with explosive RVF outbreaks in endemic areas (Mweya

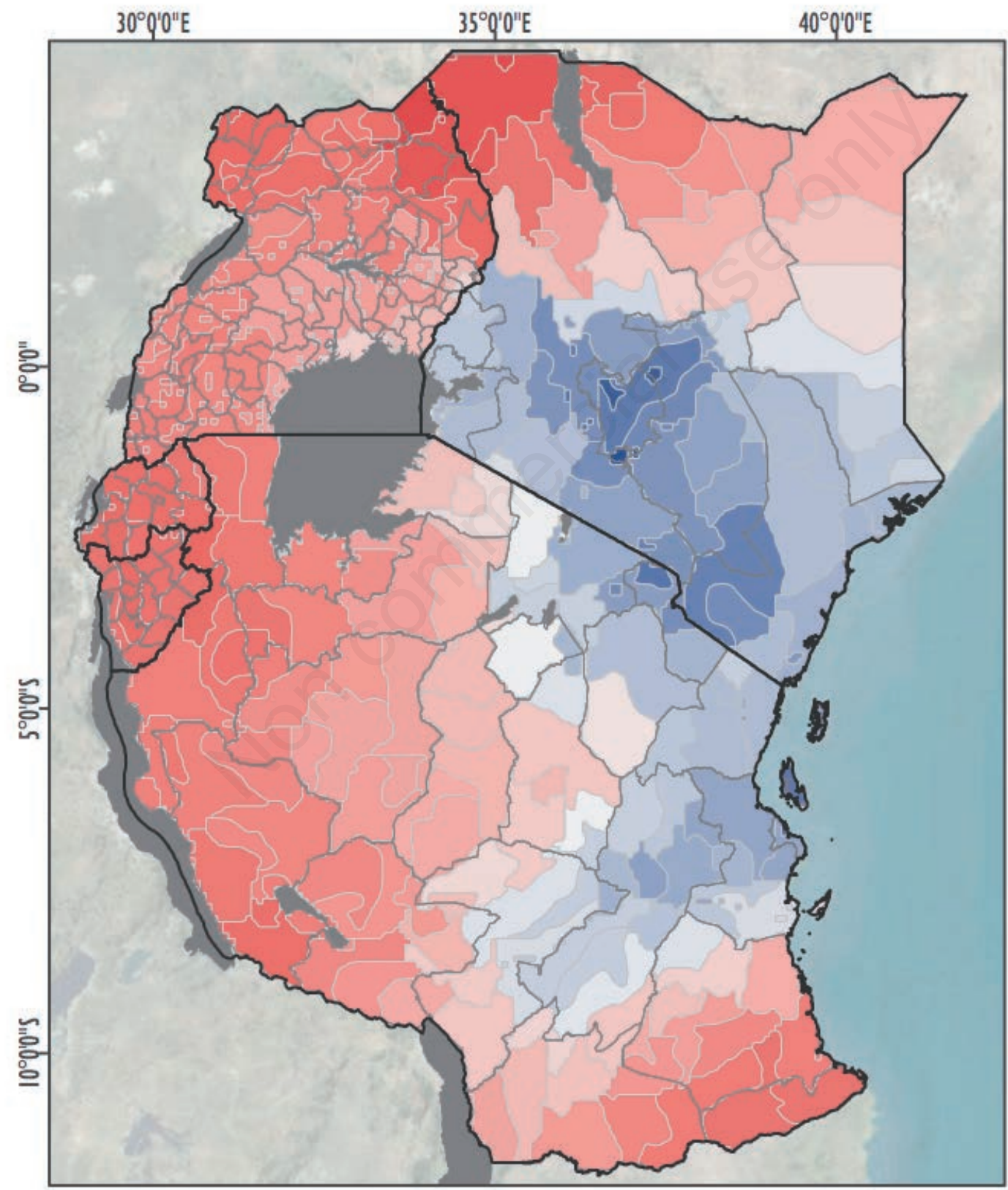

\section{Social \\ Vulnerability \\ Index}

$-100$
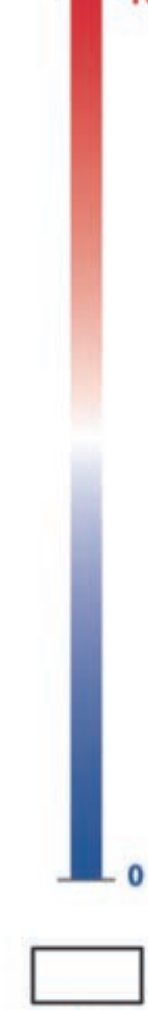

National

boundaries

Sub-National boundaries (Provinces)

Figure 6. Spatially varying vulnerability to Rift Valley fever in East African Community countries, based on nine indicators of social vulnerability. Note that vulnerability was held constant over time for this analysis. 
et al., 2015), on the basis of a statistical model (Mweya et al., 2013), and provides further evidence that the hazard of RVF outbreaks in eastern Africa extends beyond current epizootic limits. Projected EIR remains relatively stable to 2050 when compared with baseline, even declining in central/eastern Uganda (RCP4.5), before increasing by century end. Positive changes in EIR are most evident to the west of Lake Victoria (Burundi, Rwanda and western Uganda) and in western Kenya, and especially for RCP8.5 by century end, and presumably reflect the movement of RVFV into previously cooler higher altitude parts of the region and its circulation among naïve populations. According to the indicators and expert weights used, greatest social vulnerability to RVF is distributed around the southern, western and northern peripheries of the study area (Figure 6). This is because, in general, levels of income and education and ease of access to markets and information are greatest in central and eastern parts. Predisposition to RVF is greatest in the northern extremities of the EAC, generally where the borders of northeastern Uganda, northwestern Kenya and South Sudan meet, because of the co-occurrence of highly seasonal rainfall, relatively high densities of livestock, high levels of poverty and poor infrastructure, including health services. Capacity to anticipate and ability to cope with RVF outbreaks follows a similar pattern of distribution to overall social vulnerability, with central and eastern parts of the region being advantaged by access to information, infrastructure and a familiarity with the disease. Baseline risk of RVF outbreak has a similar distribution to social vulnerability and is greatest in an arc around the western, northern and eastern shoreline of Lake Victoria that incorporates Burundi, Rwanda, northwest Tanzania, central and southern Uganda and western Kenya (Figure 7). Land bordering the northern tip of Lake Malawi in southern Tanzania is also a risk hotspot. The pattern of variation in risk is generally repeated for RCP4.5, although the risk declines in the western part of the region, particularly across southern and central Uganda, and increases around the Great Rift Valley in central Kenya. For RCP8.5, patterns and variations similar to those for RCP4.5 are evident, although by end of the century the risk has expanded again in central and southern Uganda. Moreover, when compared with projections for $\mathrm{RCP} 4.5$, the risk is greater around the Great Rift Valley in central and particularly western Kenya. Projected risk remains relatively high throughout the present century for both RCP4.5 and RCP8.5 around the Western (Albertine) Rift in Burundi, Rwanda and southwestern Uganda, however.
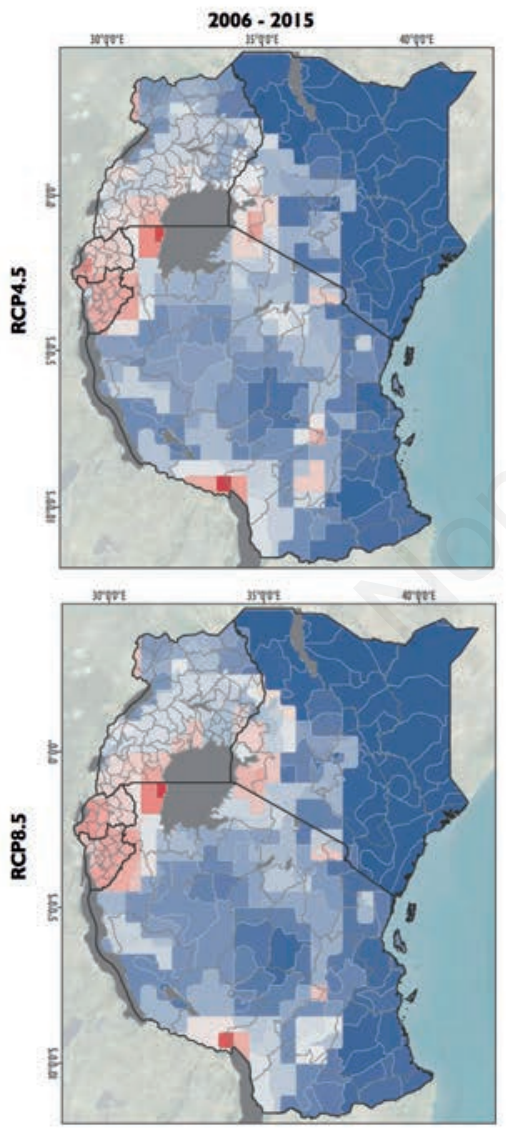
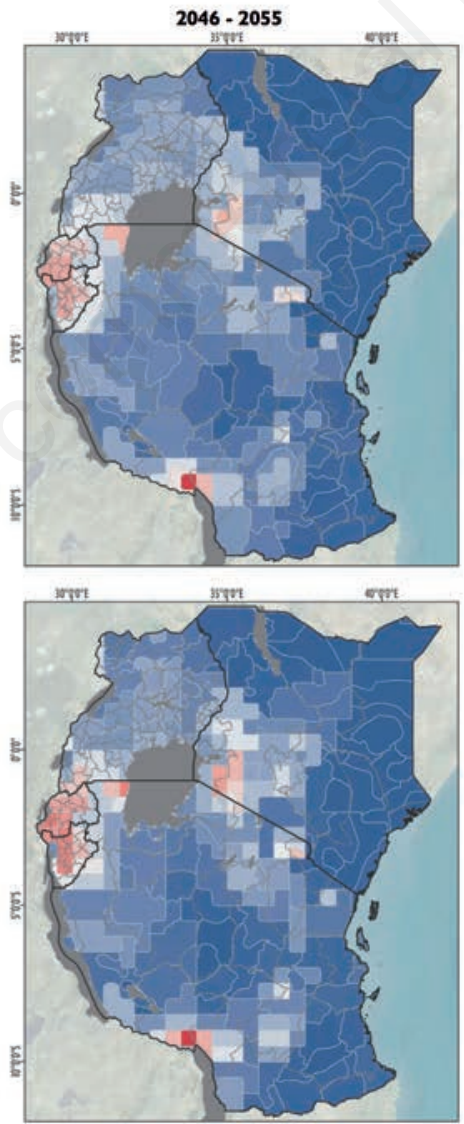
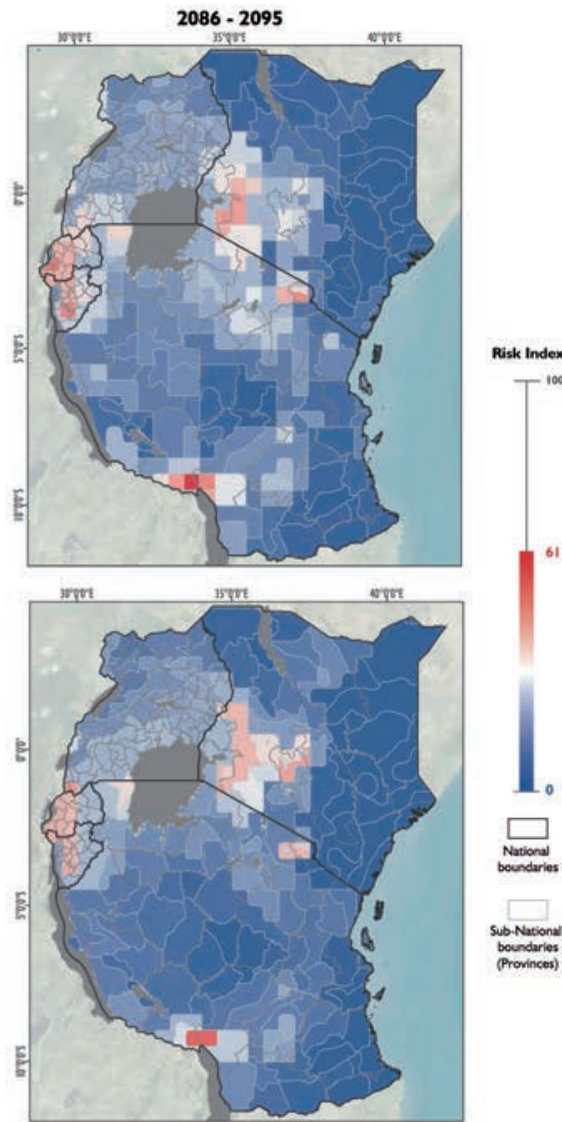

Figure 7. Plots of projected risk of Rift Valley fever outbreak among livestock in East African Community countries for three time periods: 2006-2015 (baseline), 2046-2055 (mid-century) and 2086-2095 (end of century) for two representative concentration pathways (RCPs) (RCP4.5 and RCP8.5). Risk maps are a combination of projected mean entomological inoculation rate for Culex spp. for a particular time period and assessment of vulnerability. 


\section{Discussion}

Although preliminary, the analysis of projected risk of RVF outbreak in countries comprising the EAC, using datasets and modeling and assessment tools developed through the HEALTHY FUTURES project, described in this paper highlight potentially significant spatial and temporal patterns. Spatial variations in risk, and particularly the boundaries of risk hotspots, are evident over the current century, driven by projected changes in climate. Generally the variations are more profound, and the areas of greatest risk most extensive, under the more extreme climate change scenario (represented by RCP8.5). The risk of outbreak is relatively high for the westernmost part of the EAC, comprising the generally undulating highlands of Burundi, Rwanda and southwestern Uganda associated with the Western Rift Valley, irrespective of scenario. This part of the region, which borders the Democratic Republic of the Congo (DRC), has yet to report an epizootic of RVF. Current conditions would appear to support an outbreak, and the possibility of one occurring is likely to increase as a result of climate warming, and with increases in trade (and movements of people and livestock) with other parts of the EAC and with the DRC to the west.

Outbreaks of RVF can have severe socio-economic impacts on livelihoods and nutritional security among communities where resilience is already low (Dar et al., 2013b). In addition to impacting pastoralists, RVF also effects those who work in the livestock supply chain and other parts of the wider economy, as restrictions on the movement of animals and a cessation of trade arising from outbreaks can disrupt livelihoods (Rich and Wanyoike, 2010). For example, outbreaks of RVF in 1996/1997 and 2000 led to bans on the export of live animals that had devastating economic impacts in northeastern Africa (Dar et al., 2013b). Losses following the 2000 outbreak are estimated to have exceeded US\$ 130 million in the Somali region in Ethiopia alone (Rich and Wanyoike, 2010), while Dar et al. (2013a) speculate on the wider impacts on already impoverished individuals and communities in wartorn Somalia of the opportunity costs of repeated trade bans and restrictions on animal movements. The RFV outbreak in late 2006 and early 2007 led to more than 300 deaths amongst the human population in Kenya and Tanzania, major disruptions to livelihoods and additional pressures on over-stretched public and veterinary health services, with already economically marginalised pastoralist communities in the Northeastern Province of Kenya particularly badly affected (Jost $e t$ al., 2010; Rich and Wanyoike, 2010). The mortality rate among confirmed human cases was around $16 \%$ in one study, with more cases and deaths among males than females, with the majority of those infected for whom occupation information was available having a history of direct contact with sick animals or their products (Nguku et al., 2010).

Outbreaks of RVF can also further deepen the vulnerability of impacted communities and their livestock. High rainfall associated with outbreaks in eastern and southern Africa also generally leads to improved conditions for grazing. Epizootics of RVF thus generally occur when livestock, well fed on abundant forage, would normally be expected to attract high prices at market. Because trade is severely restricted during outbreaks, herders are unable to generate income from their livestock to pay back any debts accrued during previous periods of drought and limited pasture, leading to increased borrowing and levels of destitution (Muga et al., 2015). The long period between outbreaks and the rapid rate of spread within an area once an outbreak is underway reduces the efficacy of vaccination programmes. Aside from this, the prolonged inter-epizootic periods are characterized by a loss of collective memory of the disease, and early warning signals, and by a switching of scarce health resources to what are seen as more pressing problems (Martin et al., 2008).
First recorded at the beginning of the 1930 s, following investigation of an outbreak among sheep on a farm near Naivasha, Kenya, in the Great Rift Valley (Daubney et al., 1931), RVFV may have been circulating in sub-Saharan Africa since at least the late $19^{\text {th }}$ century (Glyn Davies, 2010). According to Pépin et al. (2010), changes in food production during the colonial period, in the form of the introduction of high yielding livestock from Europe that was also highly susceptible to RVFV, may have triggered establishment and spread of the disease that was until that point largely restricted to wildlife. As such, RVF - and before RVF major epidemics of African trypanosomiasis (African sleeping sickness) during the late $19^{\text {th }}$ and early $20^{\text {th }}$ centuries (Ford, 1971) could be viewed as unforeseen negative health effects of developmentdriven changes in socio-economic and environmental conditions (Hughes and Hunter, 1970; Stock, 1986). Similarly, the introduction of irrigated agriculture, aimed at alleviating poverty and boosting nutritional security, has negatively impacted health in some areas, e.g. Ethiopia (Kibret et al., 2014), by bringing about an increased incidence of malaria - the so-called paddies paradox (Ijumba and Lindsey, 2001). Often these negative health effects of development are temporary (Baeza et al., 2013), as the associated increased wealth as a result of raised agricultural productivity eventually bring about improvements in nutrition, housing, sanitation, education and access to health services. The pathogenic landscape may be more resistant to positive changes in the case of the communities impacted by RVF outbreaks, however. This is because the negative effects extend beyond human health to also affect, directly, livelihoods. Thus, by impacting the production and trade in products from potentially high-yielding livestock RVF not only jeopardises the means of economic recovery and development, but can also lead to greater levels of indebtedness and marginalization of already highly vulnerable communities (Murithi et al., 2011).

Explosive outbreaks of RVF may be linked to limited levels of development, in the form of the acquisition of introduced breeds of highly susceptible cattle, sheep and goats that have then provided suitable conditions for the rapid amplification of the RVFV in hosts and vectors, aimed at communities with low resilience. Moreover, the limited flight capacity of the main arthropod vectors (Chevalier et al., 2004) means that the expansion of the disease since the early $20^{\text {th }}$ century in Africa is most likely due to the movement of infected livestock. These characteristics not only reinforce the importance of considering in any assessment of current and future risk the pathogenic landscapes within which RVF is maintained and outbreaks periodically occur, they also have profound implications for the distribution of risk to the disease in the EAC evident in the research presented here. Thus one of the areas of consistently high risk of RVF, highlighted in the current research, is the westernmost part of the region. Cattle form an important part of the economy on the rolling hills of Burundi, Rwanda and southwestern Uganda. Conditions appear suitable for the transmission of RVF, as they do farther to the west in the DRC. With time, and as a result of projected warming and increases in rainfall, the area of suitable habitat is likely to increase through extension to higher altitudes. Major outbreaks of RVF may be unknown in this part of the EAC simply because of its isolation and a history of reliance on relatively small herds of indigenous varieties of livestock. These factors appear to be changing too, however, which could increase the risk of future outbreaks still further. As economic integration within the EAC progresses and as political stability slowly returns to eastern DRC, movements of people and livestock within and between countries in central and eastern Africa will increase. Furthermore, initiatives such as the one cow per poor family have led to the distribution of large numbers of high yielding livestock to householders over the last decade or so, more than 130,000 since 2006 in Rwanda alone (Argenta et al., 2014). Many of these animals are housed close to where people are living, often 
sharing the same compound, and are zero-grazed (fed on fodder). As a result human-livestock contact is increased, as is the risk of zoonotic infections.

\section{Conclusions}

One of the main aims of HEALTHY FUTURES was the development of decision support frameworks (DSFs) that could maximise benefits from improved anticipations of projected environmental change-driven health impacts in the EAC. There are clear limitations in the approach and results presented in this paper. One set of factors limiting utility of the results are the uncertainties that are propagated through the different steps of the process, from projecting future climate to combining future disease hazard with spatial variations in estimates of vulnerability. In particular, the analysis is mainly based on the use of a single GCM, implying that no assessment of uncertainty due to the model formulation is possible. Likewise, a single ensemble member also prohibits any inclusion of initial condition uncertainty. The work described in this paper therefore represents a pilot demonstration of the approach of coupling dynamical modeling and vulnerability assessment frameworks to project disease risk. The intention is to expand the approach in future to include a more comprehensive treatment of uncertainty. Another issue that requires additional research is our inability, at present, to include in the analysis projections of future vulnerability in the study region together with their associated estimates of uncertainty. Notwithstanding these caveats, and in the absence of alternatives, results from HEALTHY FUTURES such as those presented here have already started to contribute to a process of developing and refining a DSF for RVF. This process involved collaboration with representatives of human and animal health agencies, both governmental and non-governmental, in EAC countries, and has sought to support a more anticipatory and participatory response to epizootics than has generally been the case to date (and see Gachohi et al., 2012). Hopefully this collaboration with practitioners will continue in the future, with scientific findings from the project providing a basis for supporting actions on the ground. Moreover, the risk of RVF is transboundary and not limited to the EAC region, while member states of the EAC are not invulnerable to the spread or re-emergence of infectious diseases originating in other parts of Africa or indeed elsewhere in the world as a result of increasing mobility, including air travel. Improving the quality of inputs to the risk-based approach, and extending the approach to a larger geographic area (as envisaged during the initial conceptualization of HEALTHY FUTURES), will be important developments of the research and results presented in this paper.

\section{References}

Anyamba A, Linthicum KJ, Small, J, Britch SC, Pak E, de La Rocque S, Formenty P, Hightower AW, Brieman RF, Chretien J-P, Crompton JT, Schnabel D, Sang R, Haagsma K, Latham M, Lewandowski HB, Magdi S0, Ally Mohamed M, Nguku PM, Reynes J-M, Swanepoel R, 2010. Prediction, assessment of the Rift Valley fever activity in East and Southern Africa 2006-2008 and possible vector control strategies. Am J Trop Med Hyg 83:43-51.

Anyamba A, Linthicum KJ, Small J, Britch SC, Tucker CJ, 2012. Remote sensing contributions to prediction and risk assessment of natural disasters caused by large-scale Rift Valley fever outbreaks. P IEEE 100:2824-34.
Anyamba A, Small JL, Britch SC, Tucker CJ, Pak EW, Reynolds CA, Crutchfield J, Linthicum KJ, 2014. Recent weather extremes and impacts on agricultural production and vector-borne disease outbreak patterns. PLoS One 9:e92538.

Argenta J, Augsburg B, Rasul I, 2014. Livestock asset transfers with and without training: evidence from Rwanda. J Econ Behav Organ 108:19-39.

Baeza A, Bouma MJ, Dhiman RC, Baskerville EB, Ceccato P, Yadav RS, Pascual M, 2013. Long-lasting transition towards sustainable elimination of desert malaria under irrigation development. P Natl Acad Sci USA 110:15157-62

Barker K, 2012. Infectious insecurities: H1N1 and the politics of emerging infectious diseases. Health Place 18:695-700.

Bartlett S, 2008, Climate change and urban children: impacts and implications for adaptation in low- and middle-income countries. Environ Urban 20:501-19.

Beaty BJ, Marquardt WC, 1996. The biology of disease vectors. University Press of Colorado, Niwot, CO, USA.

Bernstein AS, Myers SS, 2011. Climate change and children's health. Curr Opin Pediatr 23:221-6.

Bett B, Gachohi J, Mbotha D, 2013. Rift Valley fever/malaria study site analysis and major findings for Rift Valley fever and malaria transmission. Available from: https://cgspace.cgiar.org/handle/ 10568/35204

Bird BH, Ksiazek TG, Nichol ST, MacLachlan NJ, 2009. Rift Valley fever virus. JAVMA-J Am Vet Med A 234:883-93.

Blancou J, Chomel BB, Belotto A, Meslin FX, 2005. Emerging or reemerging bacterial zoonoses: factors of emergence, surveillance and control. Vet Res 36:507-22.

Burkett VR, Suarez AG, Bindi M, Conde C, Mukerji R, Prather MJ, St. Clair AL, Yohe GW, 2014. Point of departure. In: Field CB, Barros VR, Dokken DJ, Mach KJ, Mastrandrea MD, Bilir TE, Chatterjee M, Ebi KL, Estrada Y0, Genova RC, Girma B, Kissel ES, Levy AN, MacCracken S, Mastrandrea PR, White LL, eds. Climate change 2014: impacts, adaptation, and vulnerability. Part A: Global and sectoral aspects. Contribution of Working Group II to the Fifth Assessment Report of the Intergovernmental Panel on Climate Change. Cambridge University Press, Cambridge, UK, pp 169-94.

Campbell-Lendrum D, Manga L, Bagayoko M, Sommerfield J, 2015. Climate change and vector-borne diseases: what are the implications for public health research and policy? Philos T Roy Soc B 370:20130552.

Chevalier V, de la Rocque S, Baldet T, Vial L, Roger F, 2004. Epidemiological processes involved in the emergence of vectorborne diseases: West Nile fever, Rift Valley fever, Japanese encephalitis and Crimean-Congo haemorrhagic fever. Rev Sci Tech OIE 23:535-55.

Chevalier V, Dupressoir A, Tran A, Diop OM, Gotteland C, Diallo M, Etter E, Ndiaye M, Grosbois V, Dia M, Gaidet N, Sall AA, Soti V, Niang M, 2010. Environmental risk factors of West Nile virus infection of horses in the Senegal River basin. Epidemiol Infect 138:1601-9.

Costello A, Abbas M, Allen A, Ball S, Bell S, Bellamy R, Friel S, Groce N, Johnson A, Kett M, 2009. Managing the health effects of climate change. Lancet 373:1693-733.

Curtis SE, Oven KJ, 2012. Geographies of health and climate change. Prog Hum Geogr 36:654-66.

Dar 0, Hogarth S, McIntyre S, 2013a. Tempering the risk: Rift Valley fever and bioterrorism. Trop Med Int Health 18:1036-41.

Dar 0, McIntyre S, Hogarth S, Heymann D, 2013b. Rift Valley fever and a new paradigm of research and development for zoonotic disease control. Emerg Infect Dis 19:189-93. 
Daubney R, Hudson JR, Garnham PC, 1931. Enzootic hepatitis or Rift Valley fever. An undescribed virus disease of sheep, cattle and man from East Africa. J Pathol Bacteriol 34:545-79.

Day JF, Curtis GA, Edman JD, 1990. Rainfall-directed oviposition behavior of Culex nigripalpus (Diptera: Culicidae) and its influence on St. Louis encephalitis virus transmission in Indian River County, Florida. J Med Entomol 27:43-50.

Degallier N, Favier C, Menkes C, Lengaigne M, Ramalho WM, Souza R, Servain J, Boulanger J-P, 2010. Toward and early warning system for dengue prevention: modelling climate impact on dengue transmission. Climatic Change 98:581-92.

Dickin SK, Schuster-Wallace CJ, Elliott SJ, 2013. Developing a vulnerability mapping methodology: applying the water-associated disease index to dengue in Malaysia. PLoS One 8:e63584.

Ford J, 1971. The role of the trypanosomiasis in African ecology: a study of the tsetse fly problem. Clarendon Press, Oxford, UK.

Gachohi JM, Bett B, Njogu G, Mariner JC, Jost CC, 2012. The 2006-2007 Rift Valley fever outbreak in Kenya: sources of early warning messages and response measures implemented by the Department of Veterinary Services. Rev Sci Tech OIE 31:877-87.

Gad AM, Hassan, AN, Merdan, AI, 1989. Transmission of Rift Valley feer virus by different geographic strains of Culex pipiens Egypt. J Egypt Public Health Assoc 64:363-79.

Gerdes GH, 2004. Rift Valley fever. Rev Sci Tech OIE 23:613-23.

Glyn Davies F, 2010. The historical and recent impact of Rift Valley fever in Africa. Am J Trop Med Hyg 83:73-4.

Glyn Davies F, Martin V, 2006. Recognizing Rift Valley fever. Veter Ital Ser 42:31-53.

Gottdenker NL, Steicker, DG, Faust, CL, Carroll, CR, 2015. Anthropogenic land use change and infectious diseases: a review of the evidence. Ecohealth 11:619-32.

Gubler DJ, Reiter P, Ebi KL, Yap W, Nasci R, Patz JA, 2001. Climate variability and change in the United States: potential impacts on vector- and rodent-borne diseases. Environ Health Persp 109:223-33.

Hagenlocher M, Castro MC, 2015. Mapping malaria risk and vulnerability in the United Republic of Tanzania: a spatial explicit model. Popul Health Metr 13:2.

Hoshen MB, Morse AP, 2004. A weather-driven model of malaria transmission. Malaria J 3:32.

Hughes CC, Hunter JM, 1970. Disease and 'development' in tropical Africa. Soc Sci Med 3:443-93.

Ijumba JN, Lindsay SW, 2001. Impact of irrigation on malaria in Africa: paddies paradox. Med Vet Entomol 15:1-11.

Jones BA, Grace D, Kock R, Alonso S, Rushton J, Said MY, McKeever D, Mutua F, Young J, McDermott J, Pfeiffer DU, 2013. Zoonosis emergence linked to agricultural intensification and environmental change. P Natl Acad Sci USA 110:8399-404.

Jones KE, Patel NG, Levy MA, Storeygard A, Balk D, Gittleman JL, Daszak P, 2008. Global trends in emerging infectious diseases. Nature 451:990-4.

Jost CC, Nzietcheung S, Kihu S, Bett B, Njogu G, Swai ES, Mariner JC, 2010. Epidemiological assessment of the Rift Valley fever outbreak in Kenya and Tanzania in 2006 and 2007. Am J Trop Med Hyg 83:65-72.

Kovats RS, Bouma MJ, Hajat S, Worrall E, Haines A, 2003. El Nino and health. Lancet 363:1481-9.

Kibret S, Wilson GG, Tekie H, Petros B, 2014. Increased malaria transmission around irrigation schemes in Ethiopia and the potential of canal water management for malaria vector control. Malaria $\mathrm{J}$ 13:360.

Kienberger S, Hagenlocher M, 2014. Spatial-explicit modeling of social vulnerability to malaria in East Africa. Int J Health Geogr 13:29.
Lambin EF, Tran A, Vanwambeke S0, Linard C, Soti V, 2010. Pathogenic landscapes: interactions between land, people, disease vectors, and their animal hosts. Int Health Geogr 9:54.

Lang S, Kienberger S, Tiede D, Hagenlocher M, Pernkopf L, 2014. Geons - domain-specific regionalization of space. Cartogr Geogr Inform 41:214-26.

Leedale J, Jones AE, Morse AP, 2016. A dynamic, climate-driven model of Rift Valley fever. Geospat Health 11:394.

Lindsay SW, Birley MH, 1996. Climate change and malaria transmission. Ann Trop Med Parasit 90:573-88.

Linthicum KJ, Anyamba A, Tucker CJ, Kelly PW, Myers, MF, Peters, CJ, 1999. Climate and satellite indicators to forecast Rift Valley fever epidemics in Kenya. Science 285:397-400.

Magona JW, Galiwango T, Walubengo J, Mukiibi G, 2013. Rift Valley fever in Uganda: seroprevalence and risk factor surveillance vis-àvis mosquito vectors, anti-RVF virus IgG and RVF virus neutralizing antibodies in goats. Small Ruminant Res 114:176-81.

Martin V, Chevalier V, Ceccato P, Anyamba A, De Simone L, Lubroth J, 2008. The impact of climate change on the epidemiology and control of Rift Valley fever. Rev Sci Tech OIE 27:413-26.

McMichael AJ, Montgomery H, Costello A, 2012. Health risks, present and future, from global climate change. Brit Med J 344:e1359.

Muga G0, Onyango-Ouma W, Sang R, Affognon H, 2015. Review article: sociocultural and economic dimensions of Rift Valley fever. Am J Trop Med Hyg 92:730-8.

Murithi RM, Munyua P, Ithondeka PM, Macharia JM, Hightower A, Luman ET, Brieman RF, Kariuki Njenga H, 2011. Rift Valley fever in Kenya: history of epizootics and identification of vulnerable districts. Epidemiol Infect 139:372-80.

Mweya CN, Kimera SI, Kija JB, Mboera LEG, 2013. Predicting distribution of Aedes aegypti and Culex pipiens complex, potential vectors of Rift Valley fever virus in relation to disease epidemics in East Africa. Infect Ecol Epidemiol 3:21748.

Mweya CN, Kimera SI, Mellau LSB, Mboera LEG, 2015. Inter-epidemic abundance and distribution of potential mosquito vectors for Rift Valley fever virus in Ngorongoro district, Tanzania. Glob Health Action 8:25929.

Nguku PM, Sharif SK, Mutonga D, Amwayi S, Omolo J, Mohammed 0, Farnon, EC, Gould LH, Ledeman E, Rao C, Sang R, Schnabel D, Felkin DR, Hightower A, Njenga MK, Breiman RF, 2010. An investigation of a major outbreak of Rift Valley fever in Kenya: 2006-2007. Am J Trop Med Hyg 83:5-13.

Paaijmans KP, Read AF, Thomas MB, 2009. Understanding the link between malaria risk and climate. P Natl Acad Sci USA 106:13844-9.

Pawseka JT, van Vuren JP, 2013. Rift Valley fever virus: a virus with potential for global emergence. In: Johnson N, ed. The role of animals in emerging viral diseases. Elsevier, Amsterdam, The Netherlands, pp 169-200.

Pépin M, Bouloy M, Bird BH, Kemp A, Paweska J, 2010. Rift Valley fever virus (Bunyaviridae: Phlebovirus): an update on pathogenesis, molecular epidemiology, vectors, diagnostics and prevention. Vet Res 41:61.

Peters CJ, Meegan JM, 1994. Rift Valley fever. In: Beran GW, Steele JH, eds. Handbook of zoonoses. Section B: viral zoonoses. CRC Press, Boca Raton, FL, USA, pp 403-20.

Pontes RJ, Freeman J, Oliveira-Lima JW, Hodgson JC, Spielman A, 2000. Vector densities that potentiate dengue outbreaks in a Brazilian city. Am J Trop Med Hyg 62:378-83.

Rich KM, Wanyoike F, 2010. An assessment of the regional and national socio-economic impacts of the 2007 Rift Valley fever outbreak in Kenya. Am J Trop Med Hyg 83:52-7. 
Scott CA, Robbins PF, Comrie AC, 2012. The mutual conditioning of humans and pathogens: implications for integrative geographical scholarship. Ann Assoc Am Geogr 102:977-85.

Semenza JC, 2014. Climate change and human health. Int J Environ Res Public Health 11:7347-53.

Sindato C, Karimuribo ED, Pfeiffer DU, Mboera LEG, Kivaria F, Dautu G, Bett B, Paweska JT, 2014. Spatial and temporal pattern of Rift Valley fever outbreaks in Tanzania; 1930 to 2007. PLoS One 9:e88897.

Sparke M, Anguelov D, 2012. H1N1, globalization and the epidemiology of inequality. Health Place 18:726-36.

Stock R, 1986. 'Disease and development' or 'the underdevelopment of health': a critical review of geographical perspectives on African health problems. Soc Sci Med 23:689-700.

Tantely LM, Boyer S, Fontenille D, 2015. A review of mosquitoes associated with Rift Valley fever virus in Madagascar. Am J Trop Med Hyg 92:722-9.

Turell MJ, Dohm DJ, Geden CJ, Hogsette JA, Linthicum KJ, 2010.
Potential for stable flies and house flies (Diptera: Muscidae) to transmit Rift Valley fever virus. J Am Mosquito Contr 26:445-8.

van Vuuren DP, Edmonds JA, Kainuma M, Riahi K, Thomson AM, Hibbard K, Hurtt GC, Kram T, Krey V, Lamarque JF, Masui T, Meinshausen M, Nakicenovic N, Smith SJ, Rose S, 2011. The representative concentration pathways: an overview. Climatic Change 109:5-31.

Warszawski L, Frieler K, Huber V, Piontek F, Serdeczny 0, Schewe J, 2014. The inter-sectoral impact model intercomparison project (ISI-MIP): project framework. P Natl Acad Sci USA 111:3228-32.

Weaver SC, Reisen WK, 2010. Present and future arboviral threats. Antivir Res 85:328-45.

Weiss RA, McMichael AJ, 2004. Social and environmental risk factors in the emergence of infectious diseases. Nat Med 10:70-6.

WHO 2009. Global alert and response: Rift Valley fever. Available from: http://www.who.int/csr/disease/riftvalleyfev/en/

Wilson ML, 1994. Rift Valley fever virus ecology and the epidemiology of disease emergencea. Ann NY Acad Sci 740:169-80. 